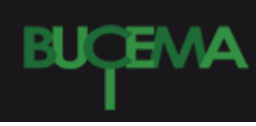

Bulletin du centre d'études médiévales d'Auxerre | BUCEMA

Hors-série $n^{\circ} 2$ | 2008

Le Moyen Âge vu d'ailleurs

\title{
A agonia lúdica : guerra, competição e fortuna nos jogos medievais
}

\section{Flavio de Campos}

\section{Q OpenEdition \\ 1 Journals}

\section{Edição electrónica}

URL: https://journals.openedition.org/cem/9452

DOI: $10.4000 /$ cem. 9452

ISSN: 1954-3093

\section{Editora}

Centre d'études médiévales Saint-Germain d'Auxerre

\section{Refêrencia eletrónica}

Flavio de Campos, "A agonia lúdica : guerra, competição e fortuna nos jogos medievais », Bulletin du centre d'études médiévales d'Auxerre | BUCEMA [En ligne], Hors-série $n^{\circ} 2$ | 2008, mis en ligne le 24 janvier 2009, consulté le 02 mars 2023. URL : http://journals.openedition.org/cem/9452 ; DOI : https:// doi.org/10.4000/cem.9452

Este documento foi criado de forma automática no dia 2 março 2023.

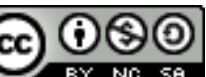

Creative Commons - Attribution - Pas d'Utilisation Commerciale - Partage dans les Mêmes Conditions 4.0 International - CC BY-NC-SA 4.0

https://creativecommons.org/licenses/by-nc-sa/4.0/ 


\title{
A agonia lúdica : guerra, competição e fortuna nos jogos medievais
}

\author{
Flavio de Campos
}

«O jogo é um corpo-a-corpo com o destino »
ANATOLE FRANCE

A análise moderna dos jogos e esportes é herdeira direta das concepções ilustradas do século XVIII. A radiação do espírito iluminista realizou-se em meio a um corpo social tecnológico - que impunha os rigores da especialização e uma nova configuração disciplinar - bafejado por certa alma romântica que insistia em buscar origens e tradições nacionais.

2 De um emaranhado de práticas lúdicas, emergia, de forma mais ou menos clara, uma ética que partia da liberdade voluntária dos praticantes, impunha a igualdade de oportunidades e condições aos concorrentes e articulava-se numa rede de fraternidade costurada pelo chamado " espírito esportivo ", capaz de banalizar vitórias e derrotas ao sustentar a máxima lúdica "o importante é competir ». Uma forma de ordenação providencial traduzida por uma outra sentença, «que vença o melhor », revelava, por outro lado, um verdadeiro clamor de justiça que se manifestava nas competições.

Os jogos e os esportes tornaram-se, assim, simultaneamente, espaços/tempos de igualdade social, mecanismos de adestramento e controle sociais e refúgios para aristocratas saudosistas e burgueses refinados ${ }^{1}$.

4 Na Encyclopédie de Diderot e d'Alambert o tema foi abordado em dois verbetes destacando a questão das virtudes e riscos envolvidos nas práticas lúdicas, tendo como paradigma os jogos de azar. Barbeyrac, no início do século XVIII, desenvolvera um quadro de práticas morais acerca dos jogos em seu Traité du jeu ou l'on examine les principales questions de droit naturel et de morale qui ont rapport à cette matière. Em ambos os casos, os jogos eram identificados como práticas frívolas, antípodas da seriedade.

5 No século XIX, a temática lúdica passou a ser associada aos instrumentos pedagógicos. Resgatava-se uma longa tradição, de certo modo ofuscada e intermitente, que remontava a Aristóteles, Quintiliano, Tomás de Aquino e Hugo de São Vítor. De toda a forma, ao mesmo tempo em que ocorria a vinculação dos jogos à educação, 
proliferaram os estudos sobre as suas origens medievais, perspectiva enquadrada na mesma grade romântica dos fundamentos nacionais, tão característico do século XIX. Assim, Joseph Strutt com o compêndio The Sports and Pastimes of People of England, em 1801 dava início ao exame da temática lúdica com relação à Idade Média, interesse que também atrairia J.Aspins, H. Alken e, principalmente, o diplomata francês J.J. Jusserand que desenvolveria suas pesquisas ao final do século XIX e que seriam reunidas e publicadas em Paris em 1901 sob o título Les sports et jeux d'exercise dans 1 'ancienne France ${ }^{2}$.

No início do século XX, H.J.R. Murray com seu A History of Chess e A. Piganiol, o companheiro de Marc Bloch e Lucien Febvre em Strasburgo, com as Recherches sur les jeux romains, são exemplos de como os estudos de determinadas modalidades lúdicas passavam a atrair o interesse dos pesquisadores.

7 Apesar de não ser o pioneiro com relação ao estudo de um amplo conjunto de comportamentos que inclui passatempos, recreações, brincadeiras, jogos e esportes, Johan Huizinga pode ser considerado como o primeiro a encetar esforços no sentido de estabelecer uma teorização no campo das ciências humanas. E, além do mais, um herdeiro confesso dessa nostalgia aristocrática do século XIX ${ }^{3}$. Com a publicação do Homo ludens em 1938, as tentativas em analisar esse tema se constituíram a partir do diálogo crítico e fecundo que a sua leitura proporciona ${ }^{4}$.

Nessa brilhante e audaciosa obra ensaística, há uma disposição em estabelecer as relações entre jogo e cultura em um arranjo no qual emerge a principal preocupação do autor : perscrutar " o que o jogo é em si mesmo e o que ele significa para os jogadores 5 ". $\mathrm{O}$ jogo, como função humana significante, era compreendido por Huizinga como uma totalidade cuja essência seria o divertimento. Uma categoria primária da vida, supralógica, capaz de criar uma ordem particular, autônoma, supérflua e frívola.

Como um verdadeiro microcosmo, o jogo estabelecer-se-ia como uma realidade fascinante, diversa da vida cotidiana, possuidora de tempos, espaços, regras, valores e objetivos específicos ${ }^{6}$. Pré-condição e solo primeiro da cultura é no jogo que a civilização teria surgido e se desenvolvido ${ }^{7}$.

10 Nas reflexões de Huizinga há uma identificação entre o lúdico e o sagrado, que se baseia na semelhança de gestos simbólicos e também no papel evasivo com respeito à vida cotidiana ${ }^{8}$ e uma certa semelhança com as festas, uma vez que o transcurso lúdico também indica uma suspensão temporária dos tempos regulares 9 .

11 Sob a mesma definição genérica do termo « jogo », Huizinga procura desenvolver uma teoria dos comportamentos lúdicos, identificando no hábito e nos impulsos do jogar a execução da cultura. Tal designação é responsável por uma instabilidade que faz com que o jogo oscile entre a natureza e a cultura, entre o instinto e o espírito, entre o humano e o sagrado, entre a seriedade e a frivolidade. Dependendo, exatamente, da modalidade ou da característica lúdica que sirva à argumentação do autor.

12 Talvez seja interessante aproveitar as reflexões de Wittgenstein que questiona a existência de uma unidade entre jogos de tabuleiro, jogos de carta, jogos de bola e jogos de combate, mas identifica parecenças e semelhanças entre eles ${ }^{10}$. Como os números, os jogos pertenceriam a uma intrincada rede de parentescos, constituindo uma família, com seus diversos agrupamentos. 
13 Na verdade, em nossa opinião, os jogos comporiam um clã, com diversas famílias cujas semelhanças forneceriam a nós elementos para a montagem de uma rede classificatória a partir das mais diversas aproximações e sobreposições ${ }^{11}$.

Além disso, a designação plural para as modalidades lúdicas, para distanciar-se de uma construção genérica que se constitua como uma invariável cultural a-histórica, deve buscar sua inteligibilidade não apenas nas significações intrínsecas. Os jogos não se revelam apenas pelas suas características estruturais, mas também no jogo de suas relações sociais. Jogo de reiterações, negações e evasões.

15 É a partir dessas considerações que pretendemos pensar a questão dos jogos no Ocidente medieval, uma civilização do jogo, saturada pelo elemento lúdico, que transformava sua própria estrutura social em um jogo ${ }^{12}$, e destinava-os a um lugar de destaque em determinados ritos sociais, como, por exemplo, as cerimônias do adubamento, realizadas em Pentecostes. Mas que os condenava de maneira contundente, a partir de matrizes constituídas pelo pensamento religioso oficial, ao menos até o século XIII, e relegava-os a festas e celebrações populares como carnavais e festas de tolos.

Santo Isidoro de Sevilha, nas suas Etimologias, examinou, significativamente, num mesmo livro, o de número XVIII, as questões referentes à guerra e aos jogos. Definiu os espetáculos de maneira genérica como os prazeres que não desonrariam por si mesmos, mas que poderiam fazê-lo dependendo do quê viesse a se desenvolver. Espetáculos que também poderiam ser denominados ludus, palavra cuja raiz seria a idolatria, associada a festas, aos jovens, e por este motivo, o bispo de Sevilha recomendava que se atentasse para a maldade de sua origem, para que não se viesse a considerar bom algo que teria tido origem no mal ${ }^{13}$.

17 Feitas as restrições iniciais, Isidoro dividia os jogos em ginásticos, circenses, gladiatórios e cênicos. Os primeiros possuiriam cinco categorias: salto (altura e distância), corrida, lançamento - pedras, lanças e flechas com arcos -, força - trabalho e levantamento de peso - e luta ${ }^{14}$. Os segundos eram subdivididos em aurigas, corridas de carros, jinetes e corridas de pedestres ${ }^{15}$. Os jogos gladiatórios, por sua vez, apresentavam-se sob a forma de diversos tipos de lutadores: eqüestres, reciários, executores, laqueários, velites e aqueles que combatiam as feras ${ }^{16}$. Por fim, o teatro era descrito através dos tipos que nele atuavam : tragediógrafos, comediógrafos, músicos, histriões, mimos e dançarinas ${ }^{17}$.

O local onde se praticava a luta, a Palestra, teria sua denominação originária do grego pale « combate ", demonstrando, assim, a estreita vinculação entre as atividades lúdicas e a prática da guerra, diversas outras modalidades de combates e até mesmo provas em que os competidores eram supliciados.

19 Ainda segundo Isidoro de Sevilha, as competições seriam denominadas certamia pelos romanos e agônes pelos gregos. De fato, como observa o autor das Etimologias, o termo agon deriva de águein que significa reunir-se em assembléia. No entanto, agônes são também os jogos e, mais especificamente, os jogos fúnebres, praticados em memória e honra dos mortos, elemento intrínseco dos cultos agonísticos na Grécia antiga que remontava às cerimônias fúnebres do período Micênico ${ }^{18}$.

20 A concepção de morte dos gregos envolvia a idéia de que a preservação da alma (psiqué) dependia de um diálogo a ser travado com os parentes e amigos vivos. É bastante conhecida a passagem da Ilíada na qual Aquiles mandara organizar jogos para 
homenagear Pátroclo morto por Heitor ${ }^{19}$. As exéquias gregas promoviam, além do sepultamento do corpo ou das cinzas, do levantamento de lápides e da prestação de sacrifícios, a celebração de jogos em honra do morto. A perda da memória, o esquecimento do morto por parte dos vivos, equivaleria à morte da alma. $\mathrm{O}$ falecido necessitava, assim, da assistência dos vivos. A memória preservava as almas dos mortos que, contemplariam os jogos disputados em sua homenagem.

21 Nos períodos Arcaico e Clássico, os jogos perderam um pouco do seu caráter fúnebre com a atribuição da titularidade dos jogos atléticos aos deuses. Entretanto, o estabelecimento dos jogos pan-helênicos, sobretudo dos Jogos Olímpicos, não modificou essencialmente os elementos litúrgicos e cerimoniais herdados das exéquias.

$\mathrm{Na}$ Roma antiga, os jogos também estiveram vinculados a homenagens aos mortos, antes de serem multiplicados nas diversas modalidades de jogos votivos, vinculados às atividades militares, e de jogos periódicos, originários de cultos propiciatórios e de rituais agrários ${ }^{20}$.

Numa também bastante conhecida passagem da Eneida, o herói Enéias convocava jogos como forma de celebrar a memória de seu pai, Anquises, ao desembarcar na ilha da Sicília, onde se encontrava o sepulcro com as suas cinzas ${ }^{21}$.

$\mathrm{Na}$ definição de Tito Lívio, os jogos eram ritos religiosos ${ }^{22}$. 0 caráter de preservação da memória dos mortos expressava-se nos sarcófagos romanos - onde inscrições externas comparavam a morte às corridas do Circo, em que carros percorriam sete pequenas voltas até desaparecer ${ }^{23}$.

25 Por outro lado, entre os muitos deuses do panteão clássico, titulares dos jogos, cabe destacar as celebrações a Jano, o deus andrógino bifronte das portas solsticiais, senhor do tríplice tempo - do presente, do passado e do futuro - e dos ciclos de existência. $\mathrm{E}$ cujas celebrações e jogos, apesar da denominação específica do mês de janeiro, ocorria tanto no solstício de inverno quanto no solstício de verão no hemisfério norte.

Como se sabe, para os gregos o conceito de tempo histórico, em oposição a um vago passado mítico, estabelecera-se por meio da elaboração das listas de vencedores dos jogos pan-helênicos, que forneciam um quadro de referência cronológica para os demais acontecimentos ${ }^{24}$. E isso é válido, também, para o mundo romano onde, as celebrações dos jogos anuais reforçavam a ritmação cronológica do tempo.

Não por acaso, ao final do século IV, santo Ambrósio, conseguira do imperador Teodósio, a proibição dos Jogos Olímpicos, a principal referência lúdica da Antigüidade Clássica. De forma geral, a condenação cristã fundamentava-se no combate ao paganismo, uma vez que os Jogos Olímpicos foram até colocados no mesmo plano que os Mistérios de Elêusis por Pausânias no século II d.C. De uma forma mais específica, o controle da significação do tempo e a disciplinarização dos cultos dos mortos estavam em causa.

28 Como aspecto fundamental da educação e da constituição da cidadania no mundo greco-romano, os jogos assumiam a função modelar para a vida pessoal e social e assemelhavam-se a ritos sociais que reforçam a unidade do grupo, através de sentimentos e laços cívicos de identidade. A paidia (jogo) estivera intimamente vinculada à paidéia (educação).

29 A cidadania clássica, artefato humano e um ingrediente da realização humana através das instituições públicas, cedia terreno, na passagem para a Idade Média, para a salvação espiritual, que remetia a realização humana à Cidade de Deus. A cidadania 
política cedia espaço, gradativamente, a uma cidadania espiritual. E uma parentela artificial muito mais vasta, constituída por toda a comunidade de fiéis, pretendia substituir o núcleo familiar responsável pelas festas e cultos em memória e benefício dos mortos. Os estertores aflitivos dos últimos instantes da vida em breve passaram a ser anunciados por um badalar específico dos sinos das igrejas cristãs que seria denominado agonia.

No entanto, até mesmo para a formação do cristão, as práticas atléticas serviam de referência modelar. A salvação da alma impunha uma rigorosa disciplina ao corpo, aludida na Primeira Epístola aos Coríntios, na qual os corredores dos estádios - onde todos correriam, mas apenas um ganharia um prêmio perecível - são comparados aos cristãos, que como ele, São Paulo, deveriam correr para obter uma coroa imperecível e tratar o próprio corpo como quem pratica o pugilato : dominando-o e reduzindo-o à servidão ${ }^{25}$.

31 Séculos depois, São Basílio Magno, um dos principais modeladores da vida cenobítica cristã, comparava a vida em comum dos monges às práticas atléticas, exercícios perpétuos e meditação nos mandamentos ${ }^{26}$.

Em lugar de explicitar a referência pagã da função dos jogos nos cultos agonísticos, Isidoro de Sevilha preferia insistir numa explicação geométrico-espacial : tais disputas celebravam-se em lugares circulares, sem ângulos, de onde agonios.

Retomando o esquema do bispo de Sevilha, se as competições ginásticas revelavam um inequívoco vínculo com as práticas da guerra através da disciplina e do fortalecimento do corpo, era em relação aos jogos circenses que Isidoro identificava, apoiado no De spectaculis de Tertuliano, a celebração aos deuses pagãos - Mercúrio, Netuno, Marte, Júpiter e Juno - identificados, evidentemente, como demônios ${ }^{27}$. Até mesmo o exercício eqüestre, " simples e de uso comum », onde não se via nenhuma malícia, era visto como algo nocivo quando associado aos jogos circenses ${ }^{28}$, cujas referências a deuses e às suas pretensas representações das origens do mundo sustentariam toda sorte de idolatria e superstições. A respeito desses jogos, advertia Santo Isidoro, o cristão deveria dar-se conta de que imundas divindades seriam os donos dos $\operatorname{circos}{ }^{29}$.

34 A advertência à loucura circense estendia-se à crueldade do anfiteatro e ao sanguinário espetáculo da arena, onde se desenrolavam os jogos gladiatórios em honra das demonizadas divindades romanas (Marte, Netuno e Vulcano).

Também era em relação aos jogos cênicos que Santo Isidoro voltava-se de forma contundente. Mais uma vez partindo de Tertuliano, porém fazendo-se acompanhar de Plauto, Cícero e Tito Lívio, o autor das Etimologias identificava nos prostíbulos a origem do teatro, onde se prostituíam as rameiras, as meretrizes, as infelizes mulheres. As tragédias eram referidas como antigas façanhas e delitos de reis criminosos e as comédias como relatos de estupros de donzelas e amores de prostitutas. Os histriões eram descritos como imitadores de mulheres impudicas. E as artes cênicas em geral gestos e flexões do corpo que expressavam uma sensualidade imprópria a um cristão acompanhadas por músicas e palavras cujos patronos eram as perigosas divindades antigas - Apolo, Musas, Minerva e Mercúrio.

36 A esse respeito, as Etimologias integravam-se a uma longa tradição de oposição ao teatro com origem em Platão e que se manifestaria fortemente entre alguns dos estóicos romanos. Apesar de ter destinado um papel especial às formas lícitas de jogo para a educação dos jovens e para a formação dos cidadãos, o filósofo grego condenara 
veementemente o teatro seja pela imitação da realidade - esta mesma uma imitação da verdade - seja pela possibilidade de levar o público a emoções que deveriam ser dominadas ${ }^{30}$.

Nas suas Confissões, Santo Agostinho revelara a paixão que nutria pelo jogo antes de sua conversão. Amor pelo jogo que se expressava na ira e na inveja quando era superado no desafio da bola pelo seu rival, na desobediência às ordens de seus pais e mestres, no orgulho quando da vitória e na preguiça que o afastava dos estudos. Mas, acima de tudo, um pecado contra o Deus providencial, ordenador e criador de todas as coisas da natureza ${ }^{31}$.

Em especial, Agostinho sentia-se atraído pelos espetáculos teatrais cheios de imagens das suas misérias e de alimento próprio para o fogo das suas paixões. E numa linha argumentativa muito próxima a Platão, indagava se não seria rematada loucura sentir prazer com cenas de sofrimento. E completava questionando a validade de um sentimento que não impelia o espectador a prestar auxílio

39 Se nas Confissões o fingimento do teatro tocava-lhe a superfície da alma, como chegou a afirmar, na Cidade de Deus o bispo de Hipona definia os jogos cênicos como espetáculos de infâmia e imundície e libertinagem de vaidades, instituídos em Roma não pelos vícios dos homens, mas por ordem dos demônios que eram tomados por deuses ${ }^{32}$.

Os alertas aos cristãos feitos por Agostinho e mesmo as considerações estóicas foram incorporadas por Santo Isidoro de Sevilha que procurava orientar os cristãos a manterem-se afastados dos levianos espetáculos teatrais.

41 Santo Isidoro reservou as linhas finais do livro de número XVIII à questão dos jogos de mesa, que não haviam sido enunciados na sua classificação inicial. Segundo o bispo de Sevilha, tais jogos teriam sido inventados pelos gregos durante os momentos de repouso da Guerra de Tróia ${ }^{33}$. Suas rápidas considerações concentram-se, sobretudo, na questão dos jogos de dados.

42 Em primeiro lugar, relatava as considerações alegóricas de alguns jogadores que praticavam o jogo com três dados para representar os três momentos da vida: presente, passado e futuro. Mais à frente, Isidoro ocupava-se dos jogos de azar, destacando os seus depravados aspectos : engano, mentira, perjúrio, ódio e ruína, o que justificava, no seu entender, a sua proibição em diversas épocas.

43 Blasfêmias, injúrias, trapaças, ganância, violência. Tais eram os aspectos identificados nos jogos de dados e que, de uma forma ou de outra, estariam sempre rondando os demais jogos na Idade Média.

44 A excelente síntese de Santo Isidoro fornece-nos valiosas pistas para a montagem de um painel inicial acerca das perspectivas teológicas em relação aos jogos ao longo da Idade Média, suas significações e suas implicações sociais.

45 As considerações acerca das atividades lúdicas passaram a alterar-se durante a Idade Média Central. A reversão do processo de ruralização verificado na Europa Ocidental com a expansão das cidades criou uma nova e intensa convivência urbana que exigiu novos padrões de comportamento e novas formas de controle social. A especialização de funções registrada nas cidades foi acompanhada pela proliferação dos divertimentos e, principalmente, das modalidades de jogos.

Na Suma Teológica ( $2^{\mathrm{a}}$ parte da $2^{\mathrm{a}}$ parte, questão 168 , art. 2-4), Tomás de Aquino indagava-se a respeito da legitimidade da diversão na vida de um cristão. Em causa estava a disciplina do corpo e da alma, a disciplina da salvação. Mas a esse respeito, 
identificava que o prazer proporcionado pelos divertimentos seria o descanso da alma. Assim,

« as palavras ou obras, com as quais só buscamos a diversão da alma, chamam-se ludicras ou jocosas. Por onde é necessário usar delas, às vezes, como de um repouso para a alma. E é o que diz o Filósofo, quando ensina, que na conversação desta vida, gozamos de um certo repouso com os divertimentos. Por onde, é necessário recorrer a eles de tempos em tempos ${ }^{34}$.»

Tomadas as devidas cautelas - e nesse aspecto o dominicano recorria a Cícero e a Santo Ambrósio para identificar os divertimentos indecorosos, impudentes, flagiciosos e obscenos, para não perder completamente a gravidade da alma e para que os divertimentos fossem convenientes à pessoa, ao tempo e ao lugar -, Tomás de Aquino identificava uma virtude ordenadora :

« Portanto, pode haver uma virtude reguladora dos divertimentos, a que o Filósofo chama eutrapélia. E a expressão - boa conversão - é a que nos faz chamar eutrapélico a quem converte acertadamente as palavras ou obras em repouso. E essa virtude, enquanto nos refreia a imoderação nos divertimentos, está contida na modéstia ${ }^{35}$. "

Assim, recomendava o prazer com moderação. Longe de ser um divertimento, a vida poderia conter momentos e atos de diversão, ordenados à recreação e ao descanso da alma. Os riscos estariam nos divertimentos excessivos que ultrapassariam a regra racional, seja pela espécie dos atos diversivos seja pelas suas inconveniências. E os jogos, juntamente com as festas e o cômico, dirigidos pela razão, seriam úteis e necessários à conversão humana. Dessa forma, até mesmo os histriões, destinados a distrair os homens, se provocassem moderadamente o divertimento, praticavam uma profissão lícita. E, mesmo que a abstenção dos divertimentos fosse menos viciosa que o superexcesso deles, a razão não exigiria a sua supressão, mas sim a sua moderação :

«A austeridade, como virtude, não exclui todos os prazeres, senão só os supérfluos e os desordenados. Por onde, pertence à afabilidade, chamada pelo Filósofo amizade ; ou à eutrapélia ou amabilidade. E contudo ele a nomeia e a define pela sua conveniência com a temperança, a que pertence regular o prazer ${ }^{36}$. »

49 As breves reflexões de Tomás de Aquino revelam uma alteração da perspectiva cristã sobre os jogos. A tendência à reprovação ao jogo, quase sempre vinculada aos diabólicos jogos de azar, cedia espaço à identificação, à discriminação de diversos tipos de jogos e ao reconhecimento de uma função virtuosa.

D. Alfonso o Sábio afirmava que os jogos eram criações humanas que permitiam realizar com plenitude a alegria que Deus desejava aos homens. Apontava três grandes grupos de jogos que se praticavam a cavalo, a pé ou sentados, e afirmava que todos esses jogos eram muito bons, "cada um no seu lugar e tempo adequados ${ }^{37}$.

51 Aliás, a renovação intelectual dos séculos XII-XIII, marcada por uma transformação dos métodos e conteúdos do ensino, foi também acompanhada pelo aparecimento de uma nomenclatura detalhada que designava e classificava os ramos e sub-ramos do saber ${ }^{38}$.

Por outro lado, o arrefecimento à oposição ao teatro, como uma das modalidades lúdicas, perceptível quando os tropos ${ }^{39}$ disseminaram-se a partir do século $\mathrm{X}$, manifestara-se claramente nas considerações de Hugo de São Vítor. $O$ teatro medieval desenvolvera-se numa sociedade que não estabelecera ainda um lugar específico para suas representações teatrais e que fizera do castelo, da igreja e da cidade seus cenários.

53 Como se sabe, em seu Didascalicon, escrito em 1127, mestre Hugo estabelece as sete ciências mecânicas como uma das quatro divisões da filosofia ${ }^{40}$. A ciência do teatro, 
para Hugo de São Vítor equivalia à ciência dos jogos ${ }^{41}$ devido ao termo em latim theatro, local onde, mais freqüentemente, o povo costumava reunir-se para brincar.

O desenvolvimento do teatro medieval receberia o impulso das influências do aristotelismo que soprava sobre os eruditos cristãos a partir do século XII e que se contrapunha às depreciativas considerações platônicas. Como para Aristóteles, a imitação era tida como natural ao homem, o teatro não procederia à imitação dos fatos, mas sim das idéias abstratas. Mais ainda, a tragédia, uma expressão cênica, dividida em prólogo, episódios e exôdo, seria a forma mais elevada de arte ${ }^{42}$.

Mestre Hugo ainda apontava outros lugares e situações destinados às práticas dos jogos antigos: cáveas onde os homens executavam coros e dançavam; ginásios onde os homens lutavam ; anfiteatros onde competiam em corridas a pé, a cavalos ou em bigas ; arenas onde pugilavam; banquetes onde tocavam músicas e arremetiam dados; santuários onde cantavam em louvor aos deuses ${ }^{43}$.

56 E lançava mão de uma definição que circunscrevia os jogos à seara humana, como ciência imitativa da natureza: Os jogos eram considerados ações legitimamente humanas, capazes de recuperar o espírito através da alegria ${ }^{44}$. E, uma vez que o povo deve, de vez em quando, reunir-se para jogar, estabeleceram-se lugares apropriados e convenientes para esses jogos, para evitar que as pessoas se reunissem indevidamente para cometerem ações condenáveis e vergonhosas ${ }^{45}$.

Ainda nessa mesma época, São Bernardo de Claraval, na Regra dos Templários, reprovava os jogos de xadrez, recém introduzidos na Europa Ocidental, associando-os aos jogos de dados ${ }^{46}$. E Dante Alighieri, quase dois séculos à frente destinava os jogadores ao sétimo círculo infernal «por terem dilapidado herança e propriedades » e convertido o prazer em mal profundo ${ }^{47}$.

58 Ainda que as considerações de Hugo de São Vítor e as de Tomás de Aquino procurassem reverter a desaprovação aos jogos, salientando sua dimensão humana mantinham-se as suspeitas sobre os indevidos jogos de azar a apontarem em sua prática a semeadura dos vícios e dos descaminhos. As suspeitas e recriminações mantêm-se, sobretudo com relação aos jogos de dados e seus praticantes. Tidos como atividades de trapaceiros, arruaceiros e pessoas fracas, capazes de arruinar suas vidas ${ }^{48}$.

59 A esse respeito, talvez seja interessante romper o invólucro moral da corrupção dos costumes com o qual os jogos de azar costumaram ser apresentados e tentar localizar o núcleo hostil à tradição cristã.

Uma primeira aproximação mostra-nos que a condenação severa aos jogos de azar pelos cristãos estivera associada ao relato bíblico que se refere à partilha das roupas de Jesus, quando da sua crucifixão. A túnica teria sido disputada através de um jogo de azar ${ }^{49}$, contaminando assim todas as demais modalidades lúdicas aos indignados olhos cristãos.

61 jogo de azar explicitaria uma afronta a Deus também pela questão do tempo e de seus usos. Como afirmou Santo Agostinho, sua paixão pelos jogos significava um pecado contra o Deus ordenador ${ }^{50}$. Um Deus providencial que não imporia nenhuma necessidade na ordem dos atos, tidos, por sua natureza, contingentes e livres, por vontade divina.

62 Mais do que perda de tempo ou distúrbios morais que afastariam de Deus, os jogos ao evocarem a sorte, em maior ou menor grau, criavam uma duração específica, um 
transcurso lúdico, uma suspensão do tempo pela inebriante sedução do jogo ${ }^{51} .0$ tempo do ludus promoveria, assim, uma ilusão : iludere.

Como apontamos inicialmente, as práticas lúdicas produziam uma ordem particular, uma realidade fascinante com diferenças e semelhanças em relação à realidade cotidiana. Tais práticas alimentariam-se duplamente da agonia. De um lado, recuperando a tensão da disputa. De outro, estabelecendo um fim, um telos, um objetivo intrínseco à atividade lúdica.

Pelas perigosas portas que permitiriam a ligação entre passado, presente e futuro, o jogador, como o combatente militar, lançava a sorte no transcurso lúdico. Significativamente, as célebres palavras de César, «Alea jacta est!» também poderiam ser traduzidas por « seja lançado o dado ».

Abria-se um tipo de atalho do tempo, uma porta que deixava o homem a mercê da Fortuna, a deusa da inconstância e da prosperidade, cujos seguidores Santo Agostinho identificara como sendo os maus que querem, injustamente, obter merecimentos ${ }^{52}$. E a quem Boécio referira-se como a malévola e arbitrária deusa que o favorecera com bens perecíveis para depois torná-lo joguete e vítima de seus caprichos.

66 Sinal que anuncia a ruína, a Fortuna seria capaz de provocar o completo desespero ao modificar arbitrariamente o curso das coisas, porque seria de sua natureza jogar o jogo interminável de girar a Roda e fazer descer o que se encontra no alto e erguer o que está embaixo ${ }^{53}$. A vida era comparável a tal roda, com fortúnios e infortúnios, que ora anda ou desanda, sem um motivo aparente.

67 Os jogos de azar transcorreriam, portanto, numa ordem específica na qual através de alegrias fugazes, provenientes da posse de bens materiais, da vaidade e do orgulho, o homem se deixaria levar pelos encantos da Fortuna, desviando-se das virtudes e afastando-se de Deus.

o complexo de idéias vinculado aos jogos de azar aproximava, no contexto do desenvolvimento urbano medieval, jogadores e usurários, unidos pelos pecados do tempo, e, talvez por isso, alocados no mesmo círculo infernal por Dante.

69 A Fortuna pagã passou a ser representada então por uma mulher, por vezes de dupla face ou de olhos vendados, que movimentava uma roda fazendo subir ou cair aqueles nela fixados.

No cristianismo medieval as antigas festas solsticiais de Jano tornaram-se as festas dos dois Joões, celebradas nas proximidades dos solstícios de inverno e de verão. Num vitral da igreja de Saint Rèmi do século XII, em Reims, são retratados dois Joões, a representar os dois solstícios, os dois rostos de Jano e os ritmos cíclicos da natureza, com a festa de inverno demarcando o início do ciclo ascendente e a festa de verão o seu inverso, o ciclo descendente. É com esse sentido que se deve retomar a frase de São João Batista registrada por João o Evangelista : «É necessário que ele cresça e eu diminua ${ }^{54}$. »

71 Enquadrada nos vitrais e nas iluminuras, a Fortuna era cantada em verso pelos goliardos, os apóstolos do jogo, do vinho e das festas, e evocada nas tavernas, nos cantos, becos e mesas nos quais se disputavam a sorte.

Por outro lado, a despeito das tentativas de enquadramento temporal levadas pela Igreja a partir do século $\mathrm{X}$, os jogos de armas permaneceram como um ingrediente indispensável à educação cavaleiresca. Os torneios, duramente criticados no Concílio de Clermont, qualificados de festas satânicas, continuaram a ser praticados em campos abertos, nos quais duas equipes, como num campo de batalha, descarregavam sua 
violência, exibiam suas habilidades guerreiras e permitiam a transferência de riquezas através da captura de armas, montarias e oponentes.

Nesse sentido, a íntima vinculação dos jogos à guerra remete a uma função utilitária principal dessas práticas lúdicas: o treinamento militar. De fato, as diversas modalidades descritas e tantos outros jogos de armas e exercícios corporais praticados ao longo de toda Idade Média (como a caça, os jogos de alvo, o jogo da quintana, equitação) faziam parte do conjunto de habilidades desenvolvido na formação do guerreiro ${ }^{55}$.

Por outro lado, a atividade centrada no confronto entre grupos organizados, aliás, como toda a modalidade lúdica, era, em última instância, um simulacro da guerra, ou um símbolo da luta entre as forças da vida e da morte com todos os seus componentes. Ao final do século XIV, o Tractatus de Ludo Scachorum apresentava explicitamente o jogo de xadrez como uma representação figurada da guerra ${ }^{56}$. Além da expressão da guerra, o jogo também atuava no sentido de sublimar e conter a violência existente na sociedade.

75 A busca de aventuras a que estavam dispostos os juvenes nos torneios, de acordo com as regras de gestão do patrimônio feudal, passaram a ser controladas a partir do século XIV. A essa altura, os torneios passaram a ser substituídos pelas justas, em geral travadas por apenas dois cavaleiros portadores de armas arredondadas de maneira a conter a violência da nobreza feudal.

Num contexto de fortalecimento das monarquias que iria culminar no enquadramento da nobreza aos padrões ditados pela realeza, não é de se espantar que também as justas tenham sido banidas por Henrique II em 1559. E que as práticas dos duelos e da esgrima, originariamente italianas, tenham se disseminado nas décadas seguintes.

Trata-se, em suma, da mesma situação que envolvia a necessidade de afirmação de unidades : territorial - com o desenvolvimento da cartografia -, religiosa - com a redefinição das supremacias e das relações entre os poderes seculares e religiosos -, política - com a expansão das prerrogativas público-estatais -, lingüística - com a elaboração das primeiras gramáticas e glossários das línguas nacionais - e histórica com as atividades de arquivistas/cronistas encarregados de elaborar e preservar a memória oficial.

Em contrapartida, e como contributo para a ação dos poderes civis, os jogos vinculavam-se cada vez mais à celebração das festas - em especial do carnaval -, às charivari e às contestações sociais. A violência e a desordem das práticas dos jogos forneciam as justificativas para as ações governamentais que restringiam o acesso a determinadas práticas lúdicas - como é o caso do jeu de paume -, modificavam o caráter de outros - como por exemplo a passagem dos torneios para as justas e depois para os duelos - e simplesmente a proibição de alguns - no caso do giuoco del calcio, do jeu de la choule e do hurling, todos antecessores do futebol.

Da virtude reguladora orientada pela razão tomista, a regulamentação do jogo passou a ser realizada tanto pelo seu próprio aperfeiçoamento intrínseco quanto pelas influências socioculturais do processo de engendramento da sociedade burguesa, da afirmação do indivíduo em termos socioculturais e do fortalecimento dos poderes civis, monárquicos ou citadinos, ao final da Idade Média.

80 É possível pensar que as sociedades européias tenham sofrido uma transformação que forçou os seus membros a uma lenta e crescente regularidade de conduta e de sensibilidade ao final da Idade Média. Nesse processo, a disciplinarização dos 
comportamentos tinha nos jogos - de azar ou de guerra - um componente tão indispensável ao controle social quanto o papel que a disciplina do trabalho viria a cumprir posteriormente ${ }^{57}$.

81 Mais uma vez é o controle do tempo que se coloca em primeiro plano. Como na disputa acerca das concepções entre o mercador e o clérigo, o jogador, como um usurário do futuro, parece usar indevidamente algo que não lhe pertence. Ou, de outra parte, o tempo dos divertimentos, o interior do transcurso lúdico, durante o qual todos os participantes tornam-se jogadores, parece ter sido palco de uma ruidosa disputa social.

\section{NOTAS}

1. Há uma interessante polêmica em torno da diferenciação entre jogos e esportes. Capitaneada pelas reflexões de Norbert Elias e Eric Dunning, pode-se identificar uma tendência em se caracterizar esportes como modalidades lúdicas desenvolvidas a partir da emergência da sociedade tecnológica que envolviam competições físicas cujo traço seria um maior limite da utilização de força física e maior controle da intensidade da violência. Contra as perspectivas consideradas puristas, por oporem o esporte ao jogo, Bernard Merdrignac em estudo recente, prefere recuperar a polissemia da palavra inglesa sport em oposição à significação restrita que acabou recebendo no início do século XIX. Veja-se a respeito : N. ELIAS, A busca da Excitação, trad., Lisboa, 1992 ; B. MERDRIGNAC, Le sport au Moyen Âge, Rennes, 2002.

2. Um interessante balanço a respeito dessa produção inicial acerca da temática lúdica pode ser encontrada em J. M. CARTER, Medieval Games. Sports and Recreations in Feudal Society, New York/London, 1992, p. 1-15.

3. Para Huizinga, a Europa do século XIX vestiu a roupa do trabalho e destinou pouco espaço para o jogo. A decadência do fator lúdico e a perda de suas características essenciais com a sistematização e a regulamentação podem ser identificadas em diversos traços comportamentais, mas, principalmente, no aparecimento do esporte moderno e na sua profissionalização esportiva, traços de um esporte profano e dessacralizado. J. HuIZINGA, Homo ludens. O jogo como elemento da cultura, trad., São Paulo, 2000 ( $4^{\mathrm{e}}$ ed.), p. 212-236.

4. Veja-se, por exemplo, J. A. G. ALCANTUD, Tractatus ludorum. Una antropológica del juego, Barcelona, 1993 ; K. BLANCHARD, The antropology os Sport. An introduction, Westport/ London, 1995 ; R. CAILloIs, Les jeux et les hommes. Le masque et le vertige, Paris, 1967 ; A. CotTA, La société ludique. La vie envahie par le jeu, Paris, 1980 ; J. DuviGnaud, El juego del juego, Santafé de Bogotá, 1997 ( $2^{e}$ ed.) ; U. Eco, « Huizinga e o Jogo ». Sobre os espelhos e outros ensaios, trad., Rio de Janeiro, 1989 ( $3^{\mathrm{e}}$ ed.), p. 269-285 ; J. HEERS, Fêtes, jeux et jouets dans les sociétés d'Occident à la fin du Moyen Âge, Montreal/Paris, 1971 ; J.-M. MeHL, Les jeux au royaume de France du XIII au début du XVI siècle, Paris, 1990.

5. J. HUIZINGA, Homo ludens..., op. cit., p. 5.

6. J. HUIZINGA, Homo ludens..., ibid., p. 3-31. 
7. Não deixa de ser significativo que quase ao mesmo tempo surgisse a obra de Norbert Elias Über den Prozess der Zivilisation estudo que procurava identificar o processo de civilização dos costumes do qual os jogos eram parte constitutiva. Ao final da Segunda Guerra, dois novos estudos procuravam discutir a questão da linguagem dos jogos e suas significações. No campo filosófico, Ludwig Wittgenstein em suas Philosophiche Untersuchungen e do ponto de vista da lingüística, Émile Benveniste com o seu « Le jeu comme structure ». 0 desenvolvimento das discussões teóricas expandiu e semeou o campo da investigação sobre os jogos. Na década de 1950, Roger Caillois apresentava sua proposta classificatória e suas críticas a Huizinga em Les jeux et les hommes.

8. Com muita precisão, Roger Caillois demonstrou que, apesar de o sagrado e o jogo se configurarem em oposição ao cotidiano, as suas polaridades são de natureza diversa. Enquanto o sagrado por definição seria puro conteúdo e o real, nessa relação frivolidade, o jogo seria pura ilusão, frágil convenção quando confrontado ao real, nessa relação, serieddade. Veja-se R. CAILLoIs, O homem e o Sagrado, trad., Lisboa, 1988, p. 150-161.

9. Marshall McLuhan afirma que o jogo é uma espécie de "paraíso artificial » ou « uma visão utópica pela qual completamos e interpretamos o significado de nossa vida diária ». Numa outra passagem, define os jogos como « situações inventadas e controladas extensões da consciência grupal, que permitem uma suspensão dos padrões costumeiros, como se a sociedade entabulasse uma conversação consigo mesma ». "Jogos. As extensões do homem ». Os meios de comunicação como extensões do Homem, trad., São Paulo, 1974 (4 ed.), p. 267 e 273.

10. Tratado lógico-filosófico e Investigações Filosóficas, trad., Lisboa, p. 227 sqq. A passagem refere-se às Investigações Filosóficas. Outros autores, como E. Benveniste e R. Caillois também apontam na mesma direção buscando compreender a diversidade das modalidades lúdicas em lugar de restringi-las a uma única e genérica denominação. Veja-se respectivamente, « Le jeu comme structure », Deucalion, 2 (1947), p. 161-167 e Les jeux et les hommes..., op. cit.

11. Poderíamos pensar diversas divisões e subdivisões para os jogos. Roger Caillois identifica as principais quatro noções de jogo : agôn (jogos de competição), alea (jogos de azar), ilinx (jogos de conhecimento) e mimicry (jogos de espetáculos), cf. Les jeux et les hommes..., ibid., p. 122. Blanchard propõe uma divisão ainda mais detalhada. Veja-se The anthropology of sport..., op. cit., p. 132. Mehl oferece uma anatomia dos jogos medievais a partir de uma classificação que ora agrupa determinadas modalidades - como por exemplo jogos de tabuleiro - ora distingue determinadas modalidades aparentadas, como o jeu de paume e la soule. Apesar do exaustivo inventário das práticas lúdicas, tal disposição menos equilibrada acaba favorecendo conclusões mais genéricas a respeito das suas características.

12. J. LE GOFF, A civilização do Ocidente Medieval, trad., Lisboa, 1995 (2 $2^{\mathrm{e}}$ ed.), v. 2 , p. 126-127. Huizinga também se refere à vida medieval como saturada pelo elemento lúdico. J. HuZINGA, Homo ludens..., op. cit., p. 200.

13. Etimologias, edición bilingüe, texto latino por W. M. LINDSAY, version española y notas por J. Oroz Reta y M.-A. M. CASQuero, Madri, 1993 (2 ed.), v. 2, p. 405.

14. Etimologias..., ibid., p. 407.

15. Etimologias..., ibid., p. 413-417.

16. Etimologias..., ibid., p. 423-425.

17. Etimologias..., ibid., p. 419-421. 
18. Veja-se a respeito M. I. FINLEY e H. W. PleKET, The Olympic Games : the first thousand years, New York, 1976, p. 19 sqq.

19. No Canto XXIII, além do sepultamento de Pátroclo, descreve-se com detalhes a corrida de carros, o pugilato e outras formas de lutas, lançamento de discos, lança e com arco. Homère, L'Iliade, ed e trad. P. MAZON, Paris, 1938, p. 97-133.

20. A. PigANIOL, Recherches sur les jeux romains, Strasbourg, 1923, p. 75-91.

21. Virgílio, Eneida, trad. T. O. SAPLDING, São Paulo, p. 89-108 (livro V).

22. "Ludorum primum initium, procurandis religionibus datum, aut religione animos, aut corpora morbis levavit ", Histoire romaine, trad. CORPET e VERGER, Paris, t. 2, p. 214 (livro VII, 3).

23. P. VeYNE, « O Império Romano », in História da vida privada, P. ARIÈs e G. DUBY, dir., trad., São Paulo, 1990, p. 211. McLuhan lembra, a respeito dos Jogos Olímpicos, que a trilha percorrida pelos corredores assemelhava-se ao circuito do zodíaco e ao curso diário do sol («Jogos. As extensões do homem »..., op. cit., p. 266).

24. C. GinZBURG, Relações de força : história, retórica, prova, São Paulo, 2002, p. 53-54.

L. MORETTI, «Olympionikai, i vincitori negli antichi agoni olimpici », in Atti dellÁcademia nazionale dei Lincei, Memorie della classe di scienze morali storiche e filologiche (s. VIII, fasc. 2), Roma, 1957, p. 105.

25. « Não sabeis que aqueles que correm no estádio, correm todos, mas um só ganha o prêmio ? Correi, portanto, de maneira a consegui-lo. Os atletas se abstêm de tudo ; eles, para ganhar uma coroa perecível ; nós porém, para ganhar uma coroa imperecível. Quanto a mim, é assim que corro, não ao incerto ; é assim que pratico o pugilato, mas não como quem fere o ar. Trato duramente o meu corpo e reduzo-o à servidão, a fim de que não aconteça que, tendo proclamado a mensagem aos outros, venha eu mesmo a ser reprovado. »

26. « A vida em comum de irmãos é estádio de atletismo, caminho excelente de progresso, exercício perpétuo e meditação dos mandamentos do Senhor. » As regras monásticas, trad., Petrópolis, 1983, p. 61.

27. Etimologias..., op. cit., p. 409-410.

28. Etimologias..., ibid., p. 409.

29. Etimologias..., ibid., p. 419.

30. Veja-se a respeito : A República, trad. e notas M. H. DA ROCHA PEREIRA, Lisboa, p. 407-408 e 471-474 [livro VIII, 568b ; livro X, 605-606a ; Cuvres complètes, trad.

E. CHAMBRY, Paris, s. d., t. 2, p. 280-282 (Górgias, 502d-e) ; CEuvres complètes, t. 5, p. 375-378 (Filebo, 48) ; Euvres complètes, t. 7, p. 280-282 (As Leis, 816d-8170)].

31. Confissões, trad., Petrópolis, 2001 ( $17^{\mathrm{e}}$ ed.), p. 33-34.

32. Cidade de Deus, trad., Petrópolis, 1991 (3e ed.), v. 1, p. 61-62, 75-76 e 175-176.

33. Etimologias..., op. cit., p. 425.

34. Suma Teológica, trad. A. CORRÊA, organização de R. COSTA e L. A. DE BONI, Porto Alegre, 1980, t. 7, p. 3248.

35. Suma Teológica..., ibid., p. 3249.

36. Suma Teológica..., ibid., p. 3252-3253.

37. "Libro del Acedrex de D. Alfonso o Sábio ", trad. e notas J. LAUAND, in O xadrez na Idade Média, São Paulo, 1988, p. 65-66.

38. Veja-se a respeito J. VERGER, Cultura, ensino e sociedade no Ocidente nos séculos XII e XIII, trad., Bauru, 2001, p. 65-87. 
39. Cânticos especiais escritos para acompanhar a música sacra em ocasiões extraordinárias, dos quais o mais antigo conhecido é Quem quaeritis trope, do século X, da Abadia Beneditina de St. Gall : Quem quaeritis in sepulchre, o Christicolae? / Jesum Nazarenum crucifixum, o coelicolae / Non est hic : Surrexit sicut praedixerat / Ite, nuniate quia surrexit de sepulchre.

40. «A mecânica contém sete ciências : ciência da lã, ciência das armas, navegação, agricultura, caça, medicina, teatro. Destas, três dedicam-se à proteção externa da natureza humana, de modo que esta natureza humana, de modo que esta natureza humana, de modo que esta natureza se protege dos incômodos, e quatro à proteção interna, pela qual a natureza se nutre, crescendo e curando-se. Trata-se de uma semelhança com o trívio e o quadrívio, porque o trívio trata das palavras exteriores, e o quadrívio dos conceitos que são concebidos no íntimo. » Didascálicon da arte de ler, intro. e trad. A. MARCHIONNI, Petrópolis, 2001, p. 111.

41. Theatrica dicitur scientia ludorum..., ibid., p. 120.

42. Poética, trad., intro. e índices E. DE SOUZA, Lisboa, 1951, p. 64.

43. Poética..., ibid., p. 121.

44. Poética..., ibid., p. 123.

45. Loca ludendi : o tradutor prefere lazer. Poética..., ibid.

46. Apud J.-M. MEHL, Les jeux..., op. cit., p. 118. Entre as diversas modalidades de xadrez, algumas envolviam a utilização de dados, " para que mais breve fosse sua duração ", 0 xadrez na Idade Média, p. 83-84. Sobre as várias regras e práticas do jogo de xadrez na Idade Média veja-se H. J. R. MuRRAY, A History of Chess, Oxford, 1913, p. 452-485.

47. A Divina Comédia, trad. C. MARTINS, Belo Horizonte, 1979, v. 1, p. 195 (Inferno, canto $\mathrm{XI})$.

48. Como se pode observar em muitas passagens sobre jogos de dados de Lejeu de saint Nicolas de Jean Bodel (Paris, 1925, p. 42-45), ainda no século XII.

49. « Os soldados quando crucificaram Jesus tomaram suas roupas e repartiram em quatro partes, uma para cada soldado, e a túnica. Ora, a túnica era sem costura, tecida como uma só peça, de alto a baixo. Disseram entre si : "Não a rasguemos, mas tiremos a sorte, para ver com quem ficará”. » (Jo. 19, 23-24).

50. Confissões..., op. cit., p. 33.

51. Veja-se a esse respeito J. HuIZINGA, Homo ludens..., op. cit., p. 3-30

52. Cidade de Deus..., op. cit., p. 167.

53. A consolação da Filosofia, trad., São Paulo, 1998, p. 3-29.

54. João, 3, 30 .

55. Apesar da relativa escassez de fontes da Alta Idade Média que revelam um silêncio eloqüente, como observou B. Merdrignac, presente nas descrições de Eginhardo a respeito de Carlos Magno. Vida de Carlomagno, intro., trad. e notas por A. DE RIQUER, Barcelona, 1986, p. 92. Veja-se também o texto atribuído a Isidoro de Sevilha publicado por Merdrignac (op. cit., p. 252-253).

56. El juego del ajedrez o Dechado de Fortuna, ed. M.-J. LEMARCHAND, Madrid, 2006 ( $2^{\mathrm{e}}$ ed.).

57. K. THOMAS, « Work and leisure in pre-industrial society », Past and Present, 29 (dez 1964), p. 50-66. 
ÍNDICE

Índice geográfico: Portugal

Mots-clés: jeu, guerre

\section{AUTOR}

FLAVIO DE CAMPOS

Universidade de São Paulo 